\title{
THE EFFECT OF GREEN MARKETING THROUGH CORPORATE SOCIAL RESPONSIBILITY AND BRAND IMAGE ON THE PURCHASE INTENTION OF THE BODY SHOP CUSTOMERS IN MALANG
}

\author{
Chalimatuz ${ }^{*}$, Khusniyah Nur, Ratnawati Kusuma \\ Faculty of Economics and Business, University of Brawijaya, Indonesia \\ *E-mail: chalimatuz120@gmail.com
}

\begin{abstract}
This study discusses the influence of Green Marketing on Purchase Intention through the variables of Corporate Social Responsibility and Brand Image. Thus, the purpose is to analyze the influence of Green Marketing through Corporate Social Responsibility and Brand Image towards Purchase Intention to The Body Shop customers in Malang by using a survey on 80 respondents to test the research hypothesis and the analysis of the data was carried out by using a partial least square (PLS). The result of the research shows that Green Marketing has a significant effect to Corporate Social Responsibility, that Corporate Social Responsibility has a significant effect on Purchase Intention, that Corporate Social Responsibility has a significant effect on Brand Image, that Green Marketing has a significant effect on Brand Image, that Brand Image has a significant effect on Purchase Intention, that Green Marketing has a significant effect on purchase intention through Corporate Social Responsibility, and that Green Marketing has a significant effect on Purchase Intention through Brand Image. The conclusion of this research is that the effect of Green Marketing in improving Purchase Intention through Corporate Social Responsibility activities is proven to be more effective than the effect of Green Marketing on the improvement of Purchase Intention through Consumer perception of The Body Shop Brand Image.
\end{abstract}

\section{KEY WORDS}

Green marketing, corporate social responsibility, brand image, purchase intention.

Today, people are increasingly aware of the importance of environmental conservation. This is because of the great concern about the possibility of natural disaster that threatens, not only health but also the survival of human and its descendants. Scientists and environmentalists have pointed some evidence concerning that issue, one of which is the phenomenon of the thinner ozone layer which can lead to skin cancer, global climate change, and also global warming. Those reasons, of course, strengthen the worry of the society. Besides that, there is another big problem which is the increasing amount of, mostly, waste that cannot be recycled (Wibowo, 2002).

Marketers' attention on the environment is increasing as environmental issues begin to emerge. This phenomenon is marked by the implementation of international environmental standards or better known as ISO-14000. ISO-14000 is an environmental management system that can provide assurance to producers and consumers that when the system is implemented, the goods produced/consumed either in the form of waste, used products, or even the service has undergone various processes that consider the efforts and rules of environmental management.

The environmental issues which are discussed in developed countries have been developed and started since the 1990s. Currently, consumer buying behavior and habits are directed at the issue of environmental preservation. The polling in the United States has consistently shown that most of the US population reflects themselves as an environmentalist (Shrum, 2005). In 2004, an advertising agency conducted another poll which showed the fact that from $82 \%$ respondents, at least $5 \%$ of them are willing to pay more for eco-friendly products, the percentage has increased by about $49 \%$ compared to previous year. A study by Shrum (2005) also showed the results from the research of Advertising Age magazine that $70 \%$ of all respondents stated that their decisions to purchase 
a regular brand or product have been influenced by eco-friendly messages on labels, advertising, packaging, and green marketing strategy applied by the company.

Consumer awareness of the environment increasingly raises a change in the pattern of buying behavior. In the selection of products, consumers tend to be more sensitive. They tend to choose environmentally friendly products offered by marketers--the situation that eventually sparked the so-called green consumerism. Green consumerism is a sustainable global consumerism movement which begins with the emergence of consumer awareness towards the environment and its rights to obtain such safe, feasible, and environmentally friendly products.

The desired product is not a product that is literally in green, but a product that can reduce the impact of the potential damage. The research conducted by Ferry (2011) has shown that green consumers have a strong believe towards the current worsening environmental conditions so that it becomes the attention of all people thus it affected the needs and desires in making purchases also the willingness to pay more for products that are environmentally friendly. This factor is known as the severity of environmental problems. The company starts to implement strategies on the application of environmental issues in line with the emergence of public awareness towards environmental concerns, which then called as a green marketing strategy.

The advanced development of cosmetics business provides a great opportunity to companies who want and have not entered the cosmetics industry sector. Indonesian Cosmetics Association (Persatuan Kosmetik Indonesia or Petosmi) states that each month the earned cosmetic sales for large-scale companies could reach for about IDR 40 billion (Darmadji, 2008). By that, it can be concluded that the use of cosmetics in Indonesia is quite large and those cosmetics become a must-have item for women in general.

The Body Shop is one of the famous companies engaged in the skincare industry and is a pioneer company in implementing a green marketing strategy. According to Ferrinadewi (2005), cosmetics are unique; besides it acts as basic needs (especially women), this item is also a means for consumers to clarify their identity in the community. In addition to that, cosmetics actually have a risk of usage that needs to be concerned because there is some content of chemicals which do not always give the same effect on every consumer.

Consumers are faced with a wide selection of cosmetics that frequently confuse them to make a decision. Choosing the wrong products can be a fatal to our skin and face even health. The Body Shop offers different things that are products with environmentally friendly materials, natural, and no animal testing. Environmentally friendly is a basic principle of The Body Shop that is owned from the beginning and, from there, came the ideas to recharge, reuse, and recycle something they can reuse. The magnitude of the business role acts as a determinant of the direction of change that is reflected in the emergence of triple bottom lines approach that leads to the success of a business. The approach is derived from the three supporting pillars such as profit, people, and the planet. So, profit is not the only source of energy for a company's survival (Haryadi, 2009).

Without the planet (environmental aspect) and the people (social aspect), a company will find it difficult to stay victorious in the long run. It must be acknowledged that this approach still has to undergo a long journey and in-depth research to become a business ethic in all companies. Therefore, Anita Roddick, the founder of The Body Shop, explains The Body Shop's work to run its business by using the principle of triple bottom lines in which it is an example of business as unusual.

One of the things that trigger the company in implementing green marketing strategy is the motivation of ecological responsibility and environmental damage which often become the spotlight in the mass media (Dhuha, 2013). Green marketing is an aspect of corporate environmental responsibility, as for example, reprocess the exploited mining land which can then become a green area, produce eco-friendly products, use recycled packaging products as well as manage office paper waste in large quantities that can be reused creatively and innovatively. Ecologically, this has a purpose as an effort in the company's concern for environmental responsibility. 
Based on the phenomenon which has been mentioned above, green marketing is a strategy done by the company which will create customer's purchase intention based on corporate social responsibility and brand image. Green marketing has a significant effect on corporate social responsibility (Eunju et al., 2013; Punitha and Rasdi, 2013). This means that company's green marketing strategy has a major impact on corporate social responsibility. The company's green marketing is reflected in corporate social responsibility as a way to protect the environment. A green marketing company can also serve as a tool in implementing corporate social responsibility (Punitha and Rasdi, 2013). Huang (2014) in his research mentioned that corporate social responsibility gives a significant effect on purchase intention which means that if consumers have a high perception of corporate social responsibility, consumers will have high purchase intentions.

Corporate social responsibility is an issue that is dynamic, broad, and influence the interests of various parties (Hartono, 2012). That is a business commitment that contributes to sustainable economic development in cooperation with employees, employee families, stakeholders, and the whole community in order to improve the life quality. This is done by implementing and generating business that based on sincere intentions to make a positive contribution to stakeholders.

However, corporate social responsibility activities cannot always get a positive response from the investor's point of view. Corporate social responsibility activities are often not favored by investors, they argue that the company will need a cost to conducting such kind of activities because it can reduce corporate income. It cannot be denied because the company must prepare some funds to conduct corporate social responsibility activities so that the cost incurred by the company will increase. Nevertheless, long-term corporate social responsibility activities undertaken by the company can improve a good image in the eyes of consumers because they receive the direct effects of corporate social responsibility activities so that it can increase the sales and accompanied by the increased corporate income.

$\mathrm{Li}$ et al. (2013) believed that corporate social responsibility has a significant effect on brand image. This means that when a company conducts corporate social responsibility activities, the perceptions given by society to the company will have an impact on the brand image. There is a research that says green marketing has a significant influence on the brand image (Lymperopoulos et al., 2012). The research explains that companies that implement green marketing and can meet the needs of their customers' green products are likely to have a good environmental reputation and good performance in line with environmental management and green innovation.

Similarly, Chih-ching et al. (2013) stated that brand image as a set of consumer perceptions toward environmental commitment and environmental awareness that has been done by the company in green marketing activities, thus it can convince customers about the image of a brand. The brand image refers to the brand characteristic features that form the community impression. The brand image reflects the brand's evaluation, strength, and essence so that it is important for the company to maintain its image. Chih-ching et al. (2013) also mentioned in his research that brand image has a significant influence on purchase intention. This means that the higher the image of a brand in consumer's mind, the higher the purchase intention.

There is a renewal in this study that is adding the relationship between corporate social responsibility and purchase intention. The update is based on the research conducted by Semuel and Chandra (2014) and Huang et al. (2014). Huang et al. (2014) wrote that corporate social responsibility has a significant influence on purchase intention which means that when consumers have a high perception of corporate social responsibility then consumers will also have a high purchase intention. While on the other hand, the research conducted by Semuel and Chandra (2014) described that corporate social responsibility has no significant effect on purchase intention.

Various studies presented above can be discussed in current research on the impact of green marketing through corporate social responsibility and brand image towards purchase intention. The research conducted by Eunju et al. (2013) indicates that green marketing 
strategy has significant influence to corporate social responsibility, and brand image and corporate reputation have significant influence to purchase intention.

Eunju et al. (2013) proved that consumers feeling towards company's green marketing will enhance corporate social responsibility, brand image, and corporate reputation as the overall identity in relation to environmentally friendly products. In addition, good brand image and corporate reputation will increase the consumer's purchase intention. Understanding the effectiveness of green marketing can help consumers to have a strong belief in the company about environmentally friendly products, and ultimately help to achieve good business performance (Eunju et al., 2013).

This research is a development of some previous research that has been mentioned above, with the title: "The Effect of Green Marketing Through Corporate Social Responsibility and Brand Image on the Purchase Intention of the Body Shop Customers in Malang".

Based on the background as stated in the previous section, the formulation of the problems is as follows:

1. Does green marketing have a significant effect on corporate social responsibility?

2. Does corporate social responsibility have a significant effect on purchase intention?

3. Does corporate social responsibility have a significant effect on brand image?

4. Does green marketing have a significant effect on brand image?

5. Does brand image have a significant effect on purchase intention?

6. Does green marketing have a significant effect on purchase intention?

7. Does green marketing have a significant effect on purchase intention through corporate social responsibility?

8. Does green marketing have a significant effect on purchase intention through the brand image?

Research Purpose. In accordance with the formulation of the problem above, the purpose of this research is:

1. To analyze the significant influence of green marketing on corporate social responsibility.

2. To analyze the significant influence between corporate social responsibility towards purchase intention.

3. To analyze the significant influence between corporate social responsibility towards the brand image.

4. To analyze the significant influence of green marketing on brand image.

5. To analyze the significant influence of brand image on purchase intention.

6. To analyze the significant influence of green marketing on purchase intention.

7. To analyze the significant influence of green marketing on purchase intention through corporate social responsibility.

8. To analyze the significant influence of green marketing on purchase intention through brand image.

\section{METHODS OF RESEARCH}

This research used a positivism paradigm with the quantitative approach in its implementation. Sugiyono (2013) mentioned that by using a quantitative approach, it will emphasize his analysis on numerical data or numbers processed with statistics. This quantitative approach is made in inferential research (in the purpose of hypothesis testing) and to derive a conclusion to an error probability of the rejection of the null hypothesis. Based on the use of quantitative approach, the significance of the relationship between variables or the significance of group differences in the research model can be obtained.

The research took place at The Body Shop Malang which is located at Olympic Garden Mall (MOG) 2nd floor and Malang Town Square (Matos) 1st floor because both locations are The Body Shop outlet location in Malang. The study was conducted in October 2016.

The population used in this research was the customer of The Body Shop in Malang. If the population comes out in a large number and the researcher has limitations to reach the entire population, the sampling was necessary to be done. In this case, the researcher needs 
to do the sampling that will be used in the research (Neolaka, 2014). Therefore, in this study, part of the population was determined by taking samples in order to facilitate the research.

The sample in this study was the customers who came to The Body Shop outlets in Malang. In this research, purposive sampling was used as the sampling technique. Purposive sampling is a sampling of a group on a certain target which then able to meet the criteria and provide information determined by the researcher or selected in accordance with the objectives or developed research problems (Ferdinand, 2014).

Sample criteria that are used in this research were:

1. The respondent must be seventeen years old and older ( $>17$ years). The age is based on the Law No. 23 of 2002 on Child Protection, it is an age that is no longer categorized as children, or in other words, has entered the adult age. This age becomes a potential consumer of The Body Shop products.

2. Have purchase The Body Shop products at least 1 time.

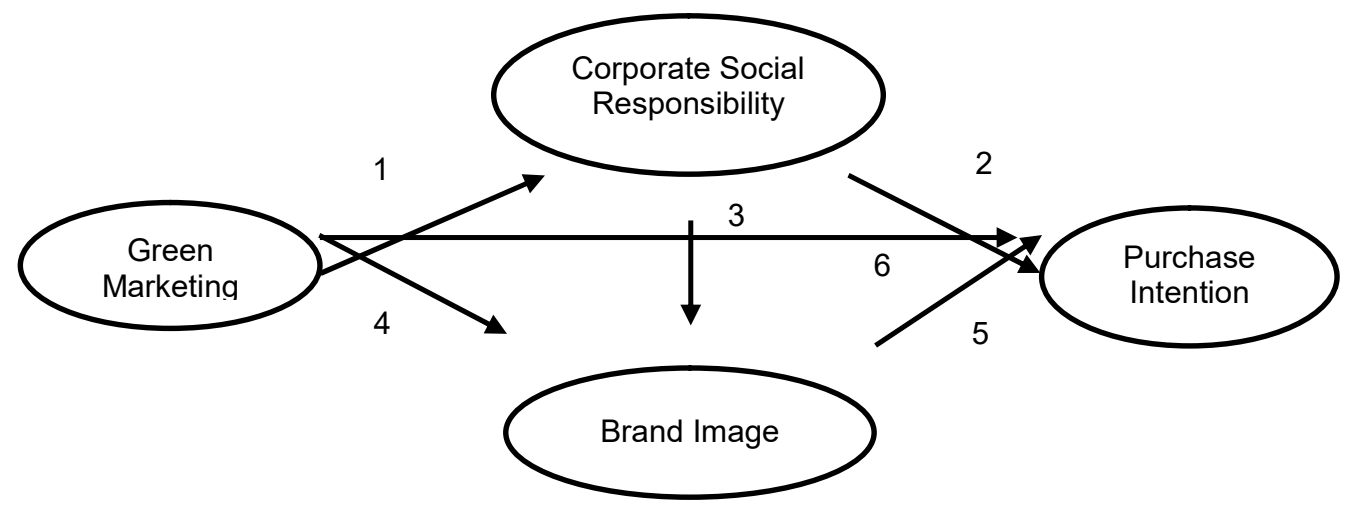

Figure 1 - Conceptual Framework of the Research

Data Collection. Sugiyono (2013) proposed that a primary data is obtained from the first source, either from individuals such as the results of questionnaires or from the interview done by researchers. The collected primary data, specifically, is used to answer the study.

The primary data in this study was obtained by distributing questionnaires on respondents to know the opinions about the influence of green marketing towards purchase intention through corporate social responsibility and brand image. This can be said that the primary data in this research was derived from questionnaires. The collection of the primary data to 80 respondents was distributed directly to the respondents in the sample research.

On the one hand, the collection method used for primary data was a survey method with a questionnaire. This questionnaire was intended only for The Body Shop customers that come to outlets and meet the sample criteria (aged 17 years and older).

The Variable Measurement Techniques in this study was carried out by using questionnaires that contain questions and provide responses by choosing one of the appropriate answers. The quantitative questionnaires were presented by using a litkert scale from 1 to 5, where: 1). Strongly disagree 2). Disagree 3). Neutral 4). Agree and 5). Strongly agree. The analysis of the data was conducted by using Smart-PLS 3.0.

\section{RESULTS AND DISCUSSION}

Research Instruments Test. Convergent validity aims to determine the validity of the relationship between indicators with latent variables. Convergent validity is known through loading factor. An instrument is said to meet the convergent validity test if the loading factor value is $>0,70$ so that the indicator or item is declared valid (Abdillah and Jogiyanto, 2015). It is known that all indicators which measure the variables of green marketing, corporate social responsibility, brand image, and purchase intention are greater than 0,7 . Thus, the indicators in this study are valid to measure the variables. 
Table 1 - Respondents Characteristics

\begin{tabular}{|c|c|}
\hline Characteristics & Frequency (\%) \\
\hline $\begin{array}{l}\text { SEX: } \\
\text { Men } \\
\text { Women } \\
\text { AGE: } \\
17-25 \text { Years } \\
26-34 \text { Years } \\
35-43 \text { Years } \\
>43 \text { Years } \\
\text { EDUCATION: } \\
\text { Senior High School } \\
\text { Diploma } \\
\text { Bachelor Degree (S1) } \\
\text { Post Graduate (S2) } \\
\text { JOB: } \\
\text { Civil Servant } \\
\text { Private Employee } \\
\text { Housewives } \\
\text { Entrepreneur } \\
\text { College Students } \\
\text { Students }\end{array}$ & $\begin{array}{l}18 \% \\
83 \% \\
\\
64 \% \\
34 \% \\
1 \% \\
1 \% \\
\\
4 \% \\
8 \% \\
75 \% \\
14 \% \\
1 \% \\
44 \% \\
1 \% \\
28 \% \\
19 \% \\
8 \%\end{array}$ \\
\hline
\end{tabular}

Table 2 - Convergent Validity Test Results

\begin{tabular}{|l|l|l|l|}
\hline \multicolumn{1}{|c|}{ Variable } & \multicolumn{1}{c|}{ AVE } & Cut Off & Status \\
\hline Green Marketing & 0,676 & 0,5 & Valid \\
\hline Corporate Social Responsibility & 0,693 & 0,5 & Valid \\
\hline Brand Image & 0,654 & 0,5 & Valid \\
\hline Purchase Intention & 0,718 & 0,5 & Valid \\
\hline
\end{tabular}

Source: Processed primary data (2016).

In the table above, we can see the convergent validity test results. Convergent validity can be seen through the loading factor and can be known through Average Variance Extracted (AVE). An instrument is said to meet the convergent validity test if it has an Average Variance Extracted (AVE) above 0,5.

The calculations that can be used to test the construct reliability are Cronbach alpha and composite reliability. The test criteria state that if the composite reliability is greater than 0,7 and the Cronbach alpha is greater than 0,6 , then the construct is declared reliable.

The results of composite reliability and Cronbach alpha can be seen in the following table:

Table 3 - Construct Reliability Test Results

\begin{tabular}{|l|l|l|l|}
\hline Variable & Composite Reliability & Cronbach's Alpha & Status \\
\hline Brand Image & 0,904 & 0,867 & Reliable \\
\hline Corporate Social Responsibility & 0,900 & 0,850 & Reliable \\
\hline Green Marketing & 0,912 & 0,880 & Reliable \\
\hline Purchase Intention & 0,927 & 0,901 & Reliable \\
\hline
\end{tabular}

Source: Processed Primary Data (2016).

Partial Least Square (PLS) Analysis. The goodness of fit model is used to know the ability of an endogenous variable to explain the diversity of exogenous variables, or in other words, to know the contribution of exogenous variables to endogenous variables. The goodness of fit model in PLS analysis is done by using S Q-Square predictive relevance (Q2). The goodness of fit model has been summarized in the Table 4.

The significance test is used to test whether the exogenous variables are influenced by endogenous variables. The test criteria state that if the value of T-statistics $\geq$ T-table $(1,96)$, then there is a significant influence of exogenous variables to endogenous variables. The results of significance test can be known through the Table 5. 


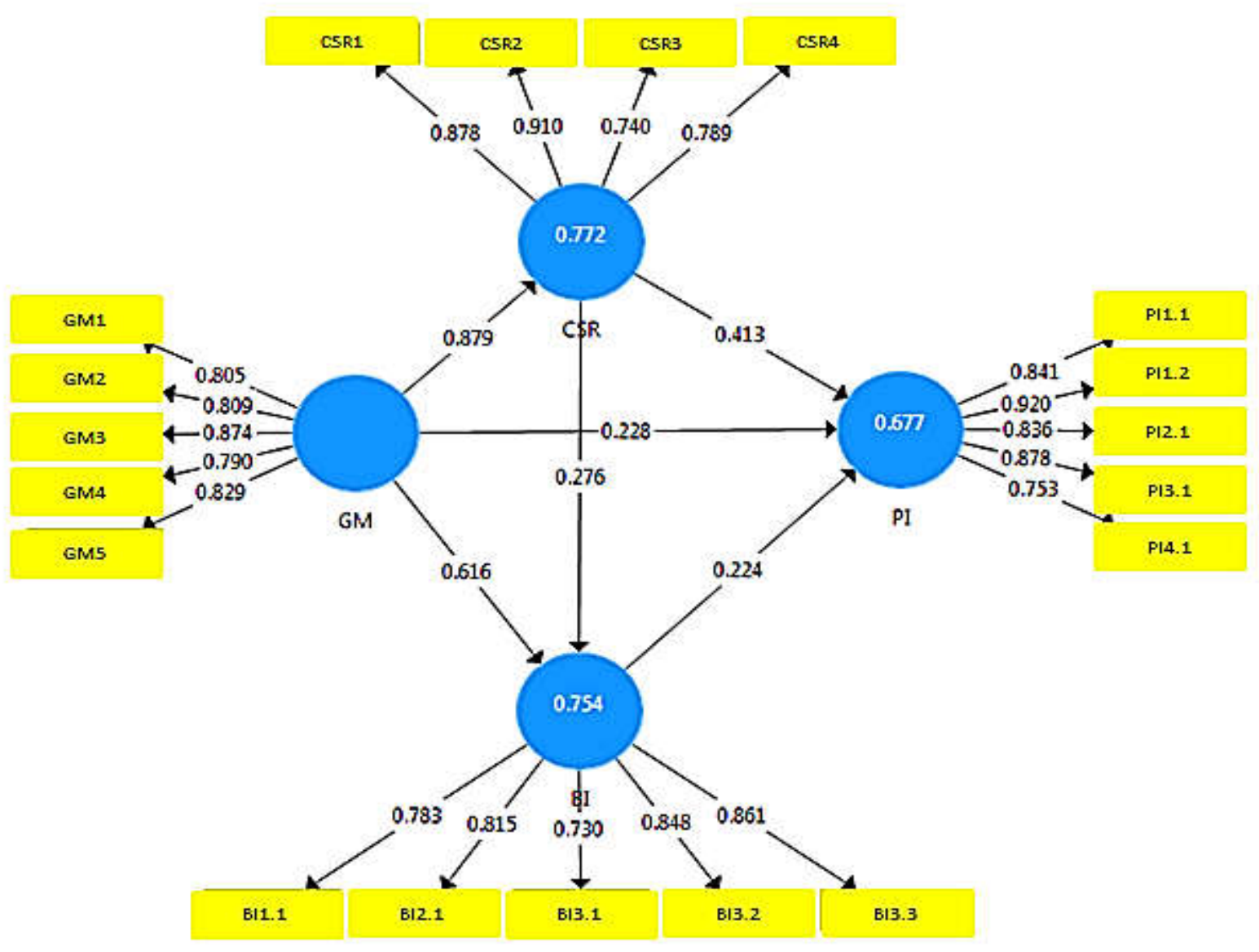

Figure 2 - Line Charts Development

Table 4 - Goodness of Fit Model

\begin{tabular}{|l|l|}
\hline \multicolumn{1}{|c|}{ Variable } & \multicolumn{1}{c|}{$R^{2}$} \\
\hline Brand Image & 0,754 \\
\hline Corporate Social Responsibility & 0,772 \\
\hline Purchase Intention & 0,677 \\
\hline $\mathrm{Q}^{2}=1-\left[\left(1-\mathrm{R}_{1}{ }^{2}\right)\left(1-\mathrm{R}_{2}{ }^{2}\right)\left(1-\mathrm{R}_{3}{ }^{2}\right)\right]$ & \\
$\mathrm{Q}^{2}=1-[(1-0,754)(1-0,772)(1-0,677)]=0,906$ & \\
\hline
\end{tabular}

Table 5 - Hypothesis Test Results

\begin{tabular}{|c|c|c|c|c|c|}
\hline Exogenous Variables & Endogenous Variables & $\begin{array}{c}\text { Original } \\
\text { Sample (O) }\end{array}$ & $\begin{array}{c}\mathrm{t}- \\
\text { statistics }\end{array}$ & $\begin{array}{c}\mathrm{t}- \\
\text { table }\end{array}$ & Status \\
\hline Green Marketing & Corporate Social Responsibility & 0,879 & 38,192 & 1,96 & $\begin{array}{c}\text { Significant } \\
\text { Influence }\end{array}$ \\
\hline $\begin{array}{c}\text { Corporate Social } \\
\text { Responsibility }\end{array}$ & Purchase Intention & 0,413 & 3,892 & 1,96 & $\begin{array}{l}\text { Significant } \\
\text { Influence }\end{array}$ \\
\hline $\begin{array}{l}\text { Corporate Social } \\
\text { Responsibility }\end{array}$ & Brand Image & 0,276 & 2,790 & 1,96 & $\begin{array}{c}\begin{array}{c}\text { Significant } \\
\text { Influence }\end{array} \\
\end{array}$ \\
\hline Green Marketing & Brand Image & 0,616 & 6,347 & 1,96 & $\begin{array}{l}\text { Significant } \\
\text { Influence }\end{array}$ \\
\hline Brand Image & Purchase Intention & 0,224 & 0,217 & 1,96 & $\begin{array}{c}\begin{array}{c}\text { Significant } \\
\text { Influence }\end{array} \\
\end{array}$ \\
\hline Green Marketing & Purchase Intention & 0,228 & 0,205 & 1,96 & $\begin{array}{l}\text { Significant } \\
\text { Influence }\end{array}$ \\
\hline
\end{tabular}

Source: Processed Primary Data (2016). 
Table 6 - Mediation Property Test Results

\begin{tabular}{|c|c|c|c|c|c|c|}
\hline $\begin{array}{c}\text { Exogenous } \\
\text { Variable }\end{array}$ & Mediation Variable & $\begin{array}{c}\text { Endogenous } \\
\text { Variable }\end{array}$ & Direct & Indirect & Total & VAF \\
\hline Green Marketing & Corporate Social Responsibility & Purchase Intention & 0,228 & 0,363 & 0,591 & 0,614 \\
\hline Green Marketing & Brand Image & Purchase Intention & 0,228 & 0,138 & 0,366 & 0,377 \\
\hline
\end{tabular}

Source: Processed Primary Data (2016).

The test of mediation properties is to determine the direct influence of independent variables on the dependent variable. VAF value above $80 \%$ indicates the role of VAF as a full mediation, whereas VAF ranging from $20 \%$ to $80 \%$ are categorized as partial mediation, and if the VAF value is less than $20 \%$, there is no mediation effect (Hair et al. 2013). The test results of Mediation Properties can be seen in Table 6.

\section{CONCLUSION}

Based on the problem formulation, the purpose and discussion in this research concerning the Switching Behavior influenced by Customer Satisfaction either directly or indirectly through Service Quality, Financial Considerations, and Convenience variables can be concluded as follows:

The majority of customers agree that the increased green marketing strategy will affect the improvement of corporate social responsibility activities conducted by The Body Shop company. Respondents agreed that the increased strategy of green marketing will enhance corporate social responsibility by The Body Shop. The assessment is based on the selling of The Body Shop eco-friendly products and recyclable packaging products, and the implementation of social activities with environmental themes so that customers can experience corporate social responsibility from The Body Shop.

Based on the results of the respondents' characteristics, it shows that most of The Body Shop customers are women. This is because the segment of The Body Shop products is women due to the products sold are facial beauty product up to body product. Women tend to be picky in determining or purchasing their beauty products. They prefer such kind of safe products and even a few who choose the products because the materials are natural ingredients.

It is proven that increasing sales of the brand in eco-friendly products is appropriate to be implemented by The Body Shop. Thus, the green marketing strategy which should be done is by increasing the sales of environmentally friendly products with environmental messages delivered on almost every product. Customers are concerned about the potential environmental impacts when someone consumes or uses the product. By that, a green marketing strategy in here brings a positive thing to be done.

The appropriate corporate social responsibility for The Body Shop is a contribution to community development. What is meant by contribution in here is that The Body Shop invites the community to take care of the environment? One simple thing that could be done is to invite customers to collect the packaging of The Body Shop ex-products that can be redeemed for certain discounts to buy new products.

In addition to that, The Body Shop also perform other social actions such as: "Choose Positive Energy" in cooperation with Greenpeace to campaign a renewable energy. More than 6 million people signed this petition (in 2000); "Get Lippy: Prevent HIV" in collaboration with MTV International to raise the awareness about HIV and AIDS (in 2008); "Stop The Trafficking of Children \& Young People" was the biggest campaign ever conducted (in 2009); "Be An Activist", to celebrate 3 (three) years partnership with UNAIDS (in 2010); and so forth.

The results of the descriptive analysis for the average of corporate social responsibility variables show that corporate social responsibility is able to make the customer feel the impact of corporate social responsibility activities conducted by The Body Shop. The customer feels that the social programs can create a wide scope of positive impacts so that purchasing The Body Shop products would generate its own benefits. The results of the descriptive analysis for the average of corporate social responsibility variables also indicate 
that the customer agrees if the improvement of corporate social responsibility activities can influence the increase of customer purchase intention.

The descriptive analysis of respondents shows that the improvement of corporate social responsibility programs will be proportional to the customer perception of The Body Shop brand image. The average value of one of the contributing items to the social environment is spelled out in the corporate social responsibility activities that have been done, one of which was in 2000 with the theme "Choose Positive Energy" in collaboration with Greenpeace to campaign such renewable energy.

All indicators are pointed to corporate social responsibility variables and, averagely, the brand image seems to receive a good assessment from the respondents. Thus, they agree that customers will have a good brand image of The Body Shop in correlation with corporate social responsibility programs. The results of the above explanation proved that the increase in corporate social responsibility can improve the brand image of The Body Shop in the customer's perspective.

The brand image of The Body Shop in the customer's perspective will appear when customers know about the company's positive actions, one of which is a green marketing strategy. Green marketing strategy is shown by one of the indicators that are an eco-friendly distribution which explains that The Body Shop sells environmentally friendly products. This points out that the use of The Body Shop products will not have an impact on environmental degradation.

The most influential brand image, in that case, is about the performance of The Body Shop. The Body Shop is more durable than similar products from other similar companies. Good performance can improve good perception from the customer side in which it makes customers believe that The Body Shop has a good brand image.

Based on the descriptive analysis of the respondents' characteristics above, it shows that the average age of The Body Shop consumers is between 17 to 25 years old. In general, an individual buys cosmetic products to support its appearance. Adolescence and adulthood are seemed to extremely keep their appearance and maintain the image of the products used. The Body Shop sells such kind of environmentally friendly products, recycled packaging materials, and plant-based ingredients so that it would not have an impact on environmental degradation.

Customers require beauty and care products that are safe for the face and body. Because beauty and health is a valuable asset for everyone. Customers require an evidence that cosmetic products and treatments are completely safe. Therefore, the Body Shop has obtained the ISO 14000 environmental certificate. It shows that The Body Shop has an environmental management system that can provide assurance (evidence) to producers and consumers. So, along with the application of the system either the used products or the produced/consumed products (waste and its services) have gone through a process that considers environmental management measures or rules.

Thus, customers will feel safe when consuming The Body Shop products because it has been proven to obtain ISO 14000 so that customers could know that The Body Shop has a good brand image. This thing that will deliver the impact on the enhancement of customer's purchase intention of The Body Shop products. All the indicators that lead to brand image and purchase intention on average will receive a good assessment from the respondents so that they will feel to increase the product sales in accordance with a good brand image that is given by The Body Shop.

It shows that customers remain loyal to buy The Body Shop products even though there are same quality products at other stores. This indicates that customers feel that the image of The Body Shop is able to increase the purchase intention because it has been proven that customers remain loyal to shop at The Body Shop.

The majority of the customers agree that rising green marketing strategies will have an impact on the improvement of various purchase intention activities from The Body Shop company. It is shown from the analysis that the customers agree that an increased green marketing strategy will increase purchase intention. 
Moreover, the analysis shows that customers remain loyal to buy The Body Shop products despite the same quality products at other stores. It shows that customers feel that the image of The Body Shop is able to increase customer's purchase intention. It is proven that customers remain loyal to shop at The Body Shop outlets.

Green marketing has an influence on purchase intention through corporate social responsibility as supported by the result of VAF calculation by 0,614 . The result is greater than the VAF calculation result in regard to green marketing that has a significant effect on purchase intention through brand image by 0,377 . So that the effect of green marketing to increase purchase intention through the activities of corporate social responsibility by The Body Shop is proven to be more effective than the influence of green marketing to increase purchase intention through consumer perception about the brand image of The Body Shop.

Huang et al. (2014) describe corporate social responsibility as a commitment of the company in an effort to meet the moral norms, economic development contributions, as well as an improved life quality for employees and the entire community. Kotler (2007) has suggested some of the reasons about the importance of corporate social responsibility activities. Corporate social responsibility can build brand positioning, increase sales, expand market share, increase employee loyalty, and increase the attractiveness of corporate investors. This can be said that the increased green marketing strategy elaborated through corporate social responsibility activities can increase purchase intention of The Body Shop products.

8. The descriptive analysis results of the respondents' characteristics indicate that the majority of respondents who used The Body Shop products has a bachelor degree. It can be concluded that the average consumer of The Body Shop is a consumer with an undergraduate education level. Consumers with higher education level (undergraduate) tend to choose a product in a rational way by observing the image of the product used/consumed.

Green marketing has an influence on purchase intention through brand image. This is proven by VAF calculation $(0,377)$. The results are known to be smaller than the VAF calculation in regard to green marketing that has a significant effect on purchase intention through corporate social responsibility by 0,614 . By that, the effect of green marketing to increase purchase intention through consumer perceptions about the brand image of The Body Shop products can be said to be more effective than the influence of green marketing to increase purchase intention through the activities of corporate social responsibility.

Research Limitations. This study was implemented through several steps that are required in scientific research and through repeated refinement process. However, in this study, there are limitations to the study which could be enhanced in future research. The limitations of this study are the variables which had an influence on purchase intention so that it needs to be reconsidered for the use of other variables such as brand equity and corporate reputation.

Currently, the income levels of the respondents in this study are unknown so that the research finding is not able to describe the characteristics to choose the products based on income. The study was carried out only on those customers who came to The Body Shop outlets in Malang. So, the generalizability of the findings is limited in the area of the research.

\section{ACKNOWLEDGEMENTS}

The authors would like to say thank you to the God for the completion of this scientific work and not to forget also for both parents and two sisters, as well as to Mrs. Dr. Nur Khusniyah Indrawati, SE., M.Si and Mrs. Dr. Kusuma Ratnawati, SE., MM. for the guidance given during the writing process. The authors also glad to thank Prof. Dr. Djumilah Hadiwidjojo, SE., and Mr. Sunaryo, SE.,M si, PhD. for the research evaluation.

\section{REFERENCES}

1. Abdillah, W. and Jogiyanto. (2015). Partial Least Square (PLS), Alternatif Structure Equation Modeling (SEM) dalam Penelitian Bisnis. CV Andi Offset, Yogyakarta. 
2. Chih-Ching, Y.L., Pei-Jou, dan Chen, C-S. (2013). How brand image, country of origin, and self-congruity influence internet users' purchase intention. Journal of Social Behavior and Personality. 41(4): 599-612.

3. Darmadji, B. (2008). Industri Kosmetik Di Indonesia. Retrieved from http://kosmetik/ JawaPos.html.

4. Dhuha, R.Y. (2013). Pengaruh Green Marketing, Corporate Social Responsibility Terhadap Brand Equity dan Costumer Loyalty (Study pada Konsumen The Body Shop di Kota Surabaya). Universitas Brawijaya Malang.

5. Eunju, K., Hwang, Y.K. and Kim, E.Y. (2013). Green Marketing' Functions in Building Corporate Image in the Retail Setting. Journal of Business Research, 66: 1709-1715.

6. Ferdinand, A. (2014). Metode Penelitian Manajemen Edisi Kelima. Badan Penerbit Universitas Diponegoro, Semarang.

7. Ferrinadewi, E. (2005). Atribut Produk yang Dipertimbangkan dalam Pembelian Kosmetik dan Pengaruhnya pada Kepuasan Konsumen di Surabaya. Jurnal Manajemen Kewirausahaan, 7(2): 139-151.

8. Ferry, J. (2011). Profil Green Consumers Indonesia: Identifikasi Segmen dan Faktor Faktor yang Mempengaruhi Perilaku Pembelian Green Products. Jurnal Mitra Ekonomi dan Manajemen Bisnis, 2(1): 18-39.

9. Hair, J.H., Ringle, T.C. and Sartstedt, M. (2013). A Primer on Partial Least Squares Structural Euation Modeling (PLS-SEM). Sage, Los Angles.

10. Hartono, R. (2012). Tanggung Jawab Sosial dan Orientasi Kepentingan Manajemen: Perspektif Manajemen. Unpublished Dissertasion. Program Doktor Ilmu Manajemen Fakultas Ekonomi dan Bisnis Universitas Brawijaya.

11. Haryadi, R. (2009). Pengaruh Strategi Green Marketing Terhadap Pilihan Konsumen Melalui Pendekatan Marketing Mix (Studi Kasus pada The Body Shop Jakarta). Semarang.

12. Huang, C-C., Yen, S-W., Liu, C-Y. and Huang, P-C. (2014). The Relationship Among Corporate Social Responsibility, Service Quality, Corporate Image And Purchase Intention. The International Journal of Organizational Innovation, 6(3).

13. Huang, Y-C., Yang, M. and Wang, Y-C. (2014). The role of animosity, religiosity and ethnocentrism on consumer purchase intention: A study in Malaysia toward European brands. Jurnal of Marketing Intelligence \& Planning, 32(3).

14. Kotler, P. (2007). Doing the Most Good for Your Company and Your Cause. Thomas Dunne Books. New York.

15. Li, Y., Hu, J., Liu, J., Liu, X. and Zheng, X. (2013). An Empirical Study on the Relationship among Corporate Social Responsibility, Brand Image and Perceived Quality. Journal of Advances in information Sciences and Service Sciences (AISS), 5(6).

16. Lymperopoulos, C., Chaniotakis, I.E. and Soureli, M. (2012). A model of green bank marketing. Journal of Financial Services Marketing, 17(2): 177-18.

17. Neolaka, A. (2014). Metode Penelitian dan Statistik. PT Remaja Rosdakarya, Bandung.

18. Punitha, S. and Rasdi, R.M. (2013). Corporate Social Responsibility: Adoption of Green Marketing by Hotel Industry. Jurnal of Asian Social Science, 9(17): 2013.

19. Semuel, H. and Chandra, S.S. (2014). The Analysis of Corporate Social Responsibility Implementation Effects towards Price Fairness, Trust and Purchase Intention at Oriflame Cosmetics Product in Surabaya. The International Conference on Communication and Media 2014 (i-COME'14), 18-20 October 2014. Langkawi, Malaysia.

20. Shrum, L. (2005). Buyer Characteristics of the Green Consumer and Their Implications for Advertising Strategy. Journal of Advertising, XXIV(2): 71-82.

21. Sugiyono. (2013). Metode Penelitian Administrasi. 20th Edition. Alfabeta. Bandung.

22. Wibowo, B. (2002). Green Consumerism dan Green Marketing Perkembangan Perilaku Konsumen dan Pendekatan Pemasaran. Usahawan, 6: 12-15. 